\title{
A-D-A-type small molecular acceptor with one hexyl-substituted thiophene as $\pi$ bridge for fullerene-free organic solar cells
}

\author{
Yongtao Liu ${ }^{1}$, Hongtao Zhang ${ }^{1,2^{*}}$, Yanna Sun ${ }^{1,2}$, Xiangjian Wan ${ }^{1,2}$ and Yongsheng Chen ${ }^{1,2}$
}

\begin{abstract}
An A-D-A-type small molecule, DCF-2HT, was synthesized using fluorene as the central block and 2-(2,3-dihydro-3-oxo-1H-inden-1-ylidene)propanedinitrile as the end groups, with one hexyl-substituted thiophene as a $\pi$ bridge, for use as an acceptor material in organic solar cells. Devices based on DCF-2HT and the polymer donors PBDB-T or PTB7-Th were fabricated and optimized. Power conversion efficiencies of $5.71 \%$ and $4.83 \%$ were obtained for PBDB-T: DCF-2HT- and PTB7-Th: DCF-2HT-based devices, respectively.
\end{abstract}

Keywords: A-D-A type, fullerene-free small molecule acceptor, side chain modifying, morphology

\section{INTRODUCTION}

Organic photovoltaics (OPVs) constitute a promising solar energy conversion technology because of their potential to enable mass production of solution-processed, lightweight, flexible, and low-cost materials $[1,2]$. In recent years, much effort has been focused on developing novel narrow-bandgap electron donor materials, and power conversion efficiencies (PCEs) above $10 \%$ have been obtained for single bulk heterojunction (BHJ) organic solar cells [3-18]. Although fullerene derivatives (such as $\mathrm{PC}_{61} \mathrm{BM}$ and $\left.\mathrm{PC}_{71} \mathrm{BM}\right)$ are commonly used as electron-acceptor materials, these acceptor materials have disadvantages like weak absorption in the visible region, difficulty in tuning the energy levels, and high production cost [19]. Recently, the use of non-fullerene acceptors, including prylene-based materials and indacenodithiophene-based acceptors, has attracted increasing attention for their breakthrough PCE of more than 10\% [20-35]. A general strategy for designing non-fullerene acceptors with a suitable energy level, good electron transport properties, and strong absorption ability has been developed.

Our group very recently reported a simple small molecular acceptor called DICTF, with fluorene as the central block and 2-(2,3-dihydro-3-oxo-1H-inden-1-ylidene)propanedinitrile as the end groups. Photovoltaic devices based on PTB7-Th:DICTF exhibited a high PCE of $7.93 \%$. Recent studies demonstrated that the side chains on the thiophene $\pi$-conjugated bridge of acceptor materials play an important role in the molecule packing behavior, and thus in the active layer morphology and device performance [36,37]. To investigate the influence of the alkyl chains on the optical and electrochemical properties and device performance, we designed the small molecule DCF-2HT (Scheme 1) by replacing the thiophene in DICTF with one hexyl chain as a $\pi$ bridge. The optical and electrochemical properties as well as the device performance of DCF-2HT were systematically investigated. PCEs of $5.71 \%$ and $4.83 \%$ were obtained for devices with PBDB-T and PTB7-Th, respectively, as the donor and DCF-2HT as the acceptor.

\section{EXPERIMENTAL SECTION}

\section{Materials}

All reactions and manipulations were performed under argon atmosphere using standard Schlenk techniques. All starting materials were purchased from commercial suppliers and used without further purification. PBDB-T and PTB7-Th were purchased from 1-Material Inc.

\footnotetext{
${ }^{1}$ The Centre of Nanoscale Science and Technology and Key Laboratory of Functional Polymer Materials, State Key Laboratory and Institute of ElementoOrganic Chemistry, Collaborative Innovation Center of Chemical Science and Engineering (Tianjin), College of Chemistry, Nankai University, Tianjin 300071, China.

${ }^{2}$ School of Materials Science and Engineering, the National Institute for Advanced Materials, Nankai University, Tianjin 300071, China.

*Corresponding author (email: htzhang@nankai.edu.cn)
} 
<smiles>[R2]c1cc(/C=C2\C(=O)c3ccccc3C2=C(C)C#N)sc1-c1ccc2c(c1)C([R7])([R])c1cc(-c3sc(/C=C4/C(=O)c5ccccc5/C4=C(\[N])C#N)cc3[R2])ccc1-2</smiles><smiles>[R3]c1ccc(-c2c3cc(-c4ccc(-c5sc(-c6ccc(C)s6)c6c5C(=O)c5c([R3])sc([R3])c5C6=O)s4)sc3c(-c3ccc([R3])s3)c3cc(C)sc23)s1</smiles><smiles></smiles>

Scheme 1 Chemical structures of DCF-2HT, PTB7-Th, and PBDB-T.

\section{Synthesis}

The synthesis route of DCF-2HT is shown in Scheme 2. DF-2HT was synthesized using Suzuki coupling reaction. The intermediate dialdehyde DCHOF-2HT was obtained by Vilsmeier-Haack reaction. The target molecule (DCF$2 \mathrm{HT}$ ) was then prepared by Knoevenagel condensation of DCHOF-2HT with 2-(2,3-dihydro-3-oxo-1H-inden-1-ylidene)propanedinitrile.

\section{Synthesis of compound DCHOF-2HT}

A Vilsmeier reagent, which was prepared using $\mathrm{POCl}_{3}$ $(1.37 \mathrm{~mL}, 15.00 \mathrm{mmol})$ in dimethylformamide $(10 \mathrm{~mL})$, was added to a solution of DF-2HT $(2.17 \mathrm{~g}, 3.00 \mathrm{mmol})$ in 1,2-dichloroethane $(80 \mathrm{~mL})$ at $0^{\circ} \mathrm{C}$. After being stirred at $65^{\circ} \mathrm{C}$ for $12 \mathrm{~h}$, the mixture was poured into ice water $(300 \mathrm{~mL})$, neutralized with $\mathrm{Na}_{2} \mathrm{CO}_{3}$, and extracted using dichloromethane. The combined organic layer was washed with water and brine and dried over $\mathrm{Na}_{2} \mathrm{SO}_{4}$. After the solvent was removed, it was chromatographed on silica gel using a mixture of dichloromethane and petroleum ether $(1: 1)$ as the eluent to afford DCHOF-2HT (1.65 g, 76\%) as a light yellow powder. ${ }^{1} \mathrm{H} \mathrm{NMR}\left(400 \mathrm{MHz}, \mathrm{CDCl}_{3}\right): \delta 9.89$ $(\mathrm{s}, 2 \mathrm{H}), 7.80(\mathrm{~d}, J=7.2 \mathrm{~Hz}, 2 \mathrm{H}), 7.71(\mathrm{~s}, 2 \mathrm{H}), 7.51-7.45(\mathrm{~m}$, $4 \mathrm{H}), 2.75(\mathrm{t}, J=7.2 \mathrm{~Hz}, 4 \mathrm{H}), 2.06(\mathrm{~m}, 4 \mathrm{H}), 1.67-1.00(\mathrm{~m}$, $40 \mathrm{H}), 0.86(\mathrm{~m}, 6 \mathrm{H}), 0.80(\mathrm{t}, J=6.8 \mathrm{~Hz}, 6 \mathrm{H}) ;{ }^{13} \mathrm{C}$ NMR $(100$ $\left.\mathrm{MHz}, \mathrm{CDCl}_{3}\right): \delta 182.7,151.6,149.1,141.1,140.9,140.3$, $138.7,132.7,128.3,123.6,120.4,56.4,40.3,31.8,31.6,30.8$, $30.0,29.7,29.2,29.1,28.9,24.0,22.6,14.0$.
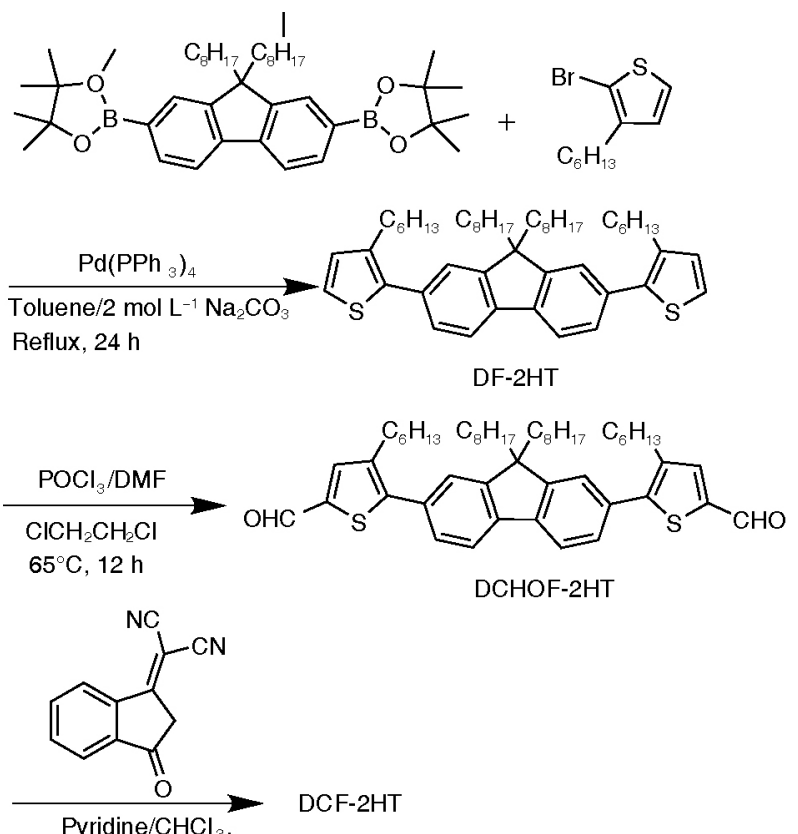

DCF-2HT

$$
25^{\circ} \mathrm{C}, 12 \mathrm{~h}
$$

Scheme 2 Synthesis route for DCF-2HT.

\section{Synthesis of compound DCF-2HT}

DCHOF-2HT (300 mg, $0.385 \mathrm{mmol}$ ) and 2-(3-oxo-2,3-dihydroinden-1-ylidene)malononitrile (INCN) $(600 \mathrm{mg}$, $0.310 \mathrm{mmol}$ ) were dissolved in a dry $\mathrm{CHCl}_{3}(50 \mathrm{~mL})$ solution, and then $1 \mathrm{~mL}$ of pyridine was added to the mixture 
under argon and stirred at room temperature for $24 \mathrm{~h}$. Then, the mixture was poured into water $(200 \mathrm{~mL})$ and extracted using $\mathrm{CHCl}_{3}$. The organic layer was washed with water and then dried over $\mathrm{Na}_{2} \mathrm{SO}_{4}$ and evaporated. The crude product was purified by silica gel using chloroform and petroleum ether (4:1) as the eluent to afford DCF-2HT as a dark blue solid (216 mg, 72\%). ${ }^{1} \mathrm{H}$ NMR $(400 \mathrm{MHz}$, $\left.\mathrm{CDCl}_{3}\right): \delta 8.88(\mathrm{~s}, 2 \mathrm{H}), 8.71(\mathrm{~d}, J=7.2 \mathrm{~Hz}, 2 \mathrm{H}), 7.94(\mathrm{~d}, J$ $=7.2 \mathrm{~Hz}, 2 \mathrm{H}), 7.86(\mathrm{dd}, J=6.8 \mathrm{~Hz}, 1.2 \mathrm{~Hz}, 2 \mathrm{H}), 7.75-7.80$ $(\mathrm{m}, 6 \mathrm{H}) 7.60(\mathrm{~d}, J=7.2 \mathrm{~Hz}, 2 \mathrm{H}), 7.53(\mathrm{~s}, 2 \mathrm{H}), 2.77(\mathrm{t}, J=$ $7.2 \mathrm{~Hz}, 4 \mathrm{H}), 2.06(\mathrm{t}, J=7.2 \mathrm{~Hz}, 4 \mathrm{H}), 1.09-1.67(\mathrm{~m}, 40 \mathrm{H})$, $0.88(\mathrm{t}, J=6.8 \mathrm{~Hz}, 6 \mathrm{H}), 0.80(\mathrm{t}, J=6.8 \mathrm{~Hz}, 6 \mathrm{H}) ;{ }^{13} \mathrm{C} \mathrm{NMR}$ $\left(100 \mathrm{MHz}, \mathrm{CDCl}_{3}\right): \delta 188.3,160.7,156.7,151.7,147.5$, $141.4,141.3,140.0,138.2,137.0,135.1,134.6,132.7,122.7$, $120.6,114.6,114.5,77.4,77.0,76.7,69.8,55.6,40.4,31.8$, 31.6, 29.4, 29.3, 29.2, 22.6, 14.1, 14.0. Anal. Calcd. for $\mathrm{C}_{75} \mathrm{H}_{78} \mathrm{~N}_{4} \mathrm{O}_{2} \mathrm{~S}_{2}$ : C, 79.61; H, 6.95. Found: C, 79.35; H, 7.72.

\section{Fabrication and characterization of organic solar cells}

The devices were fabricated with a structure of glass/indium tin oxide (ITO)/poly(3,4-ethylenedioxythiophene) polystyrene sulfonate (PEDOT:PSS)/donor:acceptor/PDIN/Al. The ITO-coated glass substrates were cleaned with deionized water, acetone, and isopropyl alcohol under ultrasonication for $15 \mathrm{~min}$ each and subsequently dried under a nitrogen flow. A PEDOT:PSS solution (Baytron P VP AI 4083, filtered at $0.45 \mu \mathrm{m}$ ) was spin-coated on the ITO substrates. After baking at $150^{\circ} \mathrm{C}$ for $20 \mathrm{~min}$, the substrates were transferred into an argon-filled glove box. Subsequently, the donor:DCF-2HT active blend layer was spin-coated from a mixed chloroform solution. A PDIN solution $\left(1.5 \mathrm{mg} \mathrm{mL}^{-1}\right.$, dissolved in methanol ( $0.2 \%$ acetic acid)) was spin-coated on top of the active layers at $3000 \mathrm{rpm}$. Finally, a $50 \mathrm{~nm} \mathrm{Al} \mathrm{layer}$ was deposited under high vacuum $\left(<1.5 \times 10^{-4} \mathrm{~Pa}\right)$. The effective area of each cell $\left(4 \mathrm{~mm}^{2}\right)$ was defined by shadow masks. The current density-voltage $(J-V)$ curves of the photovoltaic devices were obtained using a Keithley 2400 source-measure unit. The photocurrent was measured under simulated $100 \mathrm{~mW} \mathrm{~cm}^{-2}$ AM $1.5 \mathrm{G}$ irradiation provided by a xenon-lamp-based solar simulator (SAN-EI XES-70S1 (AM 1.5G)) in an argon-filled glove box. The external quantum efficiencies (EQEs) were measured using a Stanford Research Systems SR810 lock-in amplifier.

\section{Measurements and instruments}

The ${ }^{1} \mathrm{H}$ and ${ }^{13} \mathrm{C}$ NMR spectra were recorded on a Bruker AV400 or 600 Spectrometer. Thermogravimetric analysis
(TGA) was performed on a Netzsch STA 409PC instrument under a purified nitrogen gas flow at a $10^{\circ} \mathrm{C} \mathrm{min}{ }^{-1}$ heating rate. UV-vis spectra were obtained using a JASCO V-570 spectrophotometer. Cyclic voltammetry (CV) experiments were performed using an LK98B II microcomputer-based electrochemical analyzer. All CV measurements were made at room temperature with a conventional three-electrode configuration employing a glassy carbon electrode as the working electrode, a saturated calomel electrode as the reference electrode, and a Pt wire as the counter electrode. Dichloromethane was distilled from calcium hydride under dry nitrogen immediately before use. Tetrabutylammonium phosphorus hexafluoride $\left(\mathrm{Bu}_{4} \mathrm{NPF}_{6}, 0.1\right.$ mol L $\mathrm{L}^{-1}$ ) in dichloromethane was used as the supporting electrolyte; the scan rate was $100 \mathrm{mV} \mathrm{s}^{-1}$.

Atomic force microscopy (AFM) was performed using an MultiMode 8 atomic force microscope in tapping mode. Transmission electron microscopy (TEM) was performed using a Philips Technical G2F20 instrument at $200 \mathrm{kV}$.

The space-charge-limited current (SCLC) mobility was measured using a diode configuration of ITO/PEDOT:PSS/PBDB-T:DCF-2HT/Au for holes and Al/PBDB-T:DCF-2HT/Al for electrons by taking the dark current density in the range of $0-2 \mathrm{~V}$ and fitting the results to a space-charge-limited form, where the SCLC is given by:

$$
J=\frac{9 \varepsilon_{0} \varepsilon_{1} \mu_{0} V^{2}}{8 L^{3}},
$$

where $J$ is the current density, $L$ is the film thickness of the active layer, $\mu_{0}$ is the hole or electron mobility, $\varepsilon_{r}$ is the relative dielectric constant of the transport medium, $\varepsilon_{0}$ is the permittivity of free space $\left(8.85 \times 10^{-12} \mathrm{~F} \mathrm{~m}^{-1}\right)$, and $V\left(=V_{\text {appl }}\right.$ $-V_{\mathrm{bi}}$ ) is the internal voltage in the device ( $V_{\text {appl }}$ is the voltage applied to the device, and $V_{\mathrm{bi}}$ is the built-in voltage due to the work function difference between the two electrodes).

\section{RESULTS}

\section{Synthesis and thermal properties}

DCF-2HT was synthesized via a simple synthetic route (Scheme 2). The intermediate DCHOF-2HT was synthesized in $74 \%$ yield by a Stille coupling reaction under argon atmosphere with $\mathrm{Pd}\left(\mathrm{PPh}_{3}\right)_{4}$ as the catalyst for 24 h. A facile reaction of DCHOF-2HT with the compound INCN afforded DCF-2HT in $80 \%$ yield by Knoevenagel condensation under argon atmosphere using piperidine as a catalyst. The TGA plot in Fig. S1 shows good stability for DCF-2HT with a deposition temperature of $342^{\circ} \mathrm{C}$ under 
$\mathrm{N}_{2}$ atmosphere.

\section{Optical and electrochemical properties}

The solution and normalized thin film optical absorption spectra of DCF-2HT are shown in Fig. 1a. In dilute chloroform solution with a concentration of $5 \times 10^{-6} \mathrm{~mol} \mathrm{~L}^{-1}$, DCF-2HT exhibits an absorption peak at $544 \mathrm{~nm}$ with a maximum absorption coefficient of $8.72 \times 10^{4} \mathrm{~L} \mathrm{~mol}^{-1}$ $\mathrm{cm}^{-1}$. Compared to its absorption in solution, that of the DCF-2HT film presents a red-shifted maximum absorption peak at $548 \mathrm{~nm}$. The absorption region of DCF-2HT was blue-shifted compared with that of DICTF owing to the introduction of an alkyl side chain in the thiophene $\pi$-conjugated bridge. The optical band gap of DCF- $2 \mathrm{HT}$, estimated from the onset of the film spectrum, is $1.93 \mathrm{eV}$. $\mathrm{CV}$ was used to investigate the electrochemical properties of DCF-2HT (Fig. 1b). The potentials were internally calibrated using the ferrocene/ferrocenium $\left(\mathrm{Fc} / \mathrm{Fc}^{+}\right)$redox couple ( $4.8 \mathrm{eV}$ below the vacuum level). The highest occupied molecular orbital (HOMO) and lowest unoccupied molecular orbital (LUMO) energies were estimated to be -5.67 and $-3.72 \mathrm{eV}$, respectively, on the basis of the onset potentials. The HOMO energy level of DCF-2HT ( -5.67 $\mathrm{eV}$ ) is similar to that of DICTF [33]. However, the LUMO energy level $(-3.72 \mathrm{eV})$ is higher than that of DICTF $(-3.79 \mathrm{eV})$, which suggests a high $V_{\text {oc }}$ in the OPV devices using DCF-2HT as an acceptor. The electrochemical band gap of DCF-2HT is $1.95 \mathrm{eV}$, which is consistent with the value of the optical band gap. The data for the optical and electrochemical properties are summarized in Table 1.

\section{Photovoltaic properties}

First, we used PTB7-Th as the donor material and DCF-2HT as the acceptor to fabricate devices with the normal structure ITO/PEDOT:PSS/PTB7-Th:DCF2HT/PDIN/Al. PDIN is a perylene diimide derivative developed as a cathode interlayer by Li et al. [38]. The photovoltaic parameters are summarized in Table 2. The optimized device has a PCE of $4.83 \%$, which is lower than that of PTB7-Th:DICTF-based devices. However, the DCF-2HT-based devices show a higher $V_{\text {oc }}(0.97 \mathrm{~V})$ than the DICTF-based devices $(0.87 \mathrm{~V})$. Considering the relatively high HOMO of PTB7-Th and its absorption overlap with DCF-2HT, we chose another polymer, PBDB-T, as a donor to blend with DCF-2HT. After device optimization, a PCE of $5.71 \%$ was obtained. The value is nearly comparable to that of DICTF:PBDB-T devices [39]. Similar to the above active layer system, the devices with DCF-2HT had a higher $V_{\text {oc }}$ of more than $1 \mathrm{~V}$. The $J-V$ curves of the devices using PBDB-T as the electron donor material before and after optimization and the corresponding EQE spectra are shown in Fig. 2 (the $J-V$ curves of the devices using PTB7-Th as the electron donor material and the corresponding EQE spectra are presented in Fig. S2). The additive N-Ph (1-phenylnaphthalene) was used to optimize the devices and a $0.5 \%$ volume ratio compared to that of the active layer solution gave the best results. The improved $V_{\text {oc }}$ is attributed to the higher LUMO of DCF-
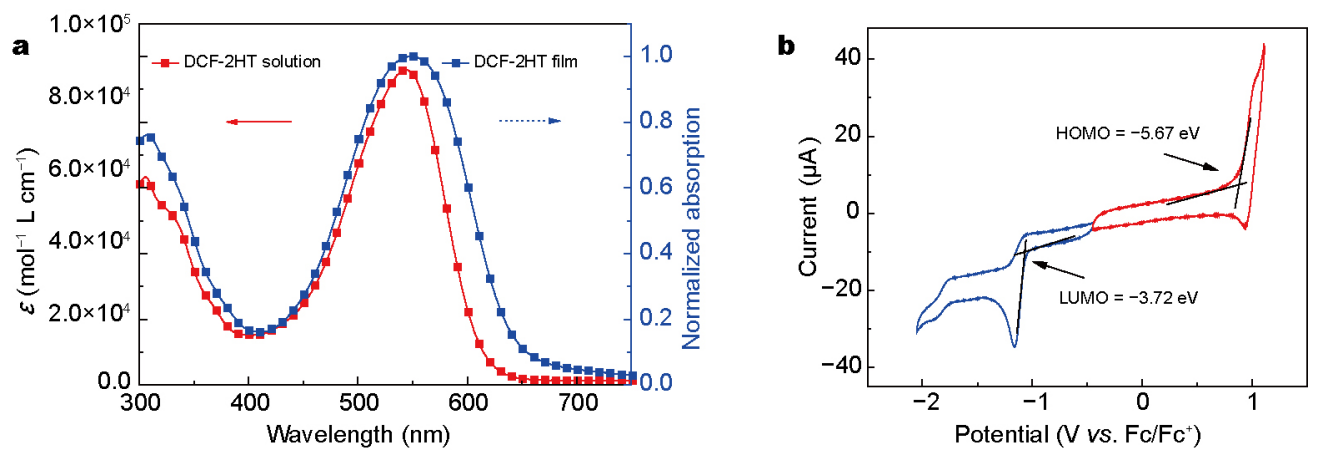

Figure 1 (a) Absorption spectra of DCF-2HT in chloroform solution and in the as-cast film; b) CV of DCF-2HT in a dichloromethane solution of 0.1 $\mathrm{mol} \mathrm{L}^{-1} \mathrm{Bu}_{4} \mathrm{NPF}_{6}$ at a scan rate of $100 \mathrm{mV} \mathrm{s}^{-1}$.

Table 1 Optical and electrochemical data for DCF-2HT

\begin{tabular}{cccccccc}
\hline Compound & $\lambda_{\max }$ solution $(\mathrm{nm})$ & $\varepsilon$ solution $\left(\mathrm{mol}^{-1} \mathrm{~L}^{-1} \mathrm{~cm}^{-1}\right)$ & $\lambda_{\max }$ film $(\mathrm{nm})$ & $E_{\mathrm{g}}{ }^{\text {opt }}$ film $(\mathrm{eV})$ & $E_{\mathrm{g}}{ }^{\mathrm{CV}}(\mathrm{eV})$ & $\mathrm{HOMO}(\mathrm{eV})$ & $\mathrm{LUMO}(\mathrm{eV})$ \\
\hline DCF-2HT & 544 & $8.7 \times 10^{4}$ & 548 & 1.93 & 1.95 & -5.67 & -3.72 \\
DICTF $^{\mathrm{a}}$ & 587 & $9.3 \times 10^{4}$ & 624 & 1.82 & 1.88 & -5.67 & -3.79 \\
\hline
\end{tabular}

a) Results from Ref. [33]. 
Table 2 Device performance parameters for BHJ solar cells based on PBDB-T:DCF-2HT and PTB7-Th:DCF-2HT

\begin{tabular}{|c|c|c|c|c|c|}
\hline Compound & Additive & $V_{\mathrm{oc}}(\mathrm{V})$ & $J_{\mathrm{sc}}\left(\mathrm{mA} \mathrm{cm}^{-2}\right)$ & $\mathrm{FF}(\%)$ & $\mathrm{PCE}^{\mathrm{a}), \mathrm{b})}(\%)$ \\
\hline PBDB-T:DCF-2HT & 0 & 1.04 & 7.13 & 31.73 & $2.36(2.25)$ \\
\hline PBDB-T:DCF-2HT & $0.5 \% \mathrm{~N}-\mathrm{Ph}$ & 1.02 & 11.30 & 49.50 & $5.71(5.56)$ \\
\hline PTB7-Th:DCF-2HT & 0 & 0.97 & 9.29 & 32.12 & $2.89(2.75)$ \\
\hline PTB7-Th:DCF-2HT & $0.5 \% \mathrm{~N}-\mathrm{Ph}$ & 0.96 & 12.43 & 40.04 & $4.83(4.67)$ \\
\hline
\end{tabular}

a) The best PCEs. b) Average values of 30 devices are provided in the parentheses.
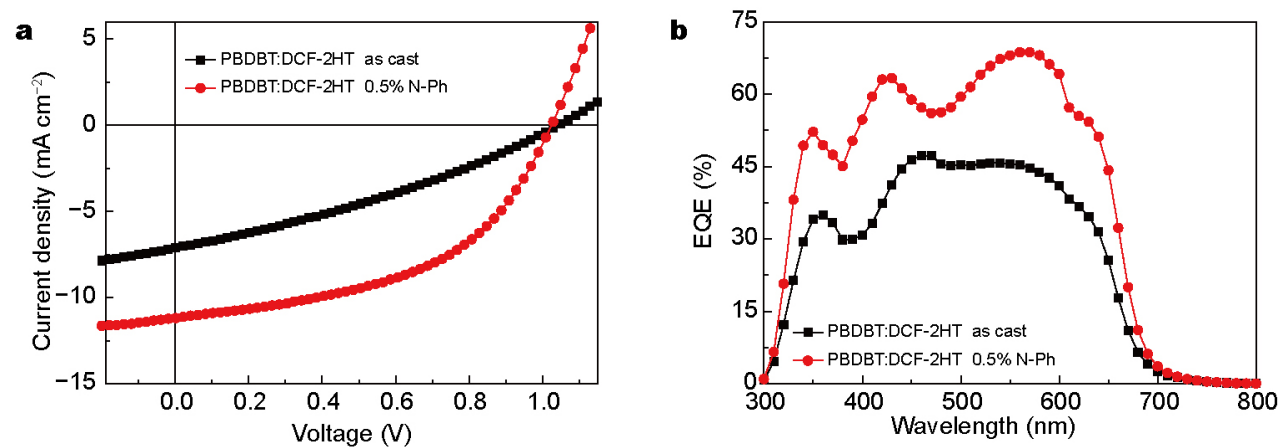

Figure 2 (a) $J-V$ curves of devices based on PBDB-T:DCF-2HT (1:1.4, wt/wt) with and without N-Ph; b) EQEs of devices based on PBDB-T:DCF-2HT $(1: 1.4, \mathrm{wt} / \mathrm{wt})$ with and without $\mathrm{N}-\mathrm{Ph}$.

2HT and the different interaction with the polymers owing to the added alkyl chains in the two thiophene units. The results indicate that side-chain engineering could be an effective strategy for designing new non-fullerene derivatives.

\section{Mobility}

The charge mobility of PBDB-T:DCF-2HT (wt/wt, 1:1.4) blend film was measured by the SCLC method. As shown in Fig. 3, for devices without any treatment, the hole and electron mobilities were $1.21 \times 10^{-5}$ and $3.34 \times 10^{-5} \mathrm{~cm}^{2} \mathrm{~V}^{-1}$ $\mathrm{s}^{-1}$, respectively. However, the hole and electron mobilities of devices with $0.5 \% \mathrm{~N}$-Ph were $1.34 \times 10^{-5}$ and $4.86 \times 10^{-5}$ $\mathrm{cm}^{2} \mathrm{~V}^{-1} \mathrm{~s}^{-1}$, respectively, which is favorable for a higher $J_{\mathrm{sc}}$ and fill factor (FF).

\section{Morphology of the PBDB-T:DCF-2HT-blend films}

The morphology of the PBDB-T:DCF-2HT-blend films was investigated using AFM and TEM (the results for the PTB7-Th:DCF-2HT film are presented in Fig. S3.) As shown in Figs $4 \mathrm{a}$ and b, the root-mean-square (RMS) surface roughness was $1.17 \mathrm{~nm}$ for the active layer without any treatment. After $0.5 \% \mathrm{~N}-\mathrm{Ph}$ was added, it increased to $1.64 \mathrm{~nm}$, which reveals that the films are smooth with high quality. Figs $4 \mathrm{c}$ and $\mathrm{d}$ show TEM images of the active layer. Compared with the as-cast film, better phase separation

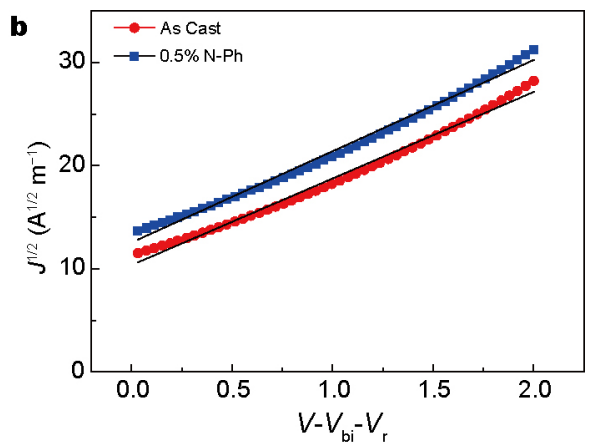

Figure 3 (a) $J-V$ characteristics of an electron-only device with the configuration ITO/Al (30 nm)/PBDB-T:DCF-2HT/Au (30 nm). (b) $J-V$ characteristics of a hole-only device with the configuration ITO/PEDOT:PSS $(30 \mathrm{~nm}) / \mathrm{PBDB}-\mathrm{T}: \mathrm{DCF}-2 \mathrm{HT} / \mathrm{Au}(30 \mathrm{~nm})$. The solid line represents the fit using a model of single-carrier SCLC with field-independent mobility. The $J_{\mathrm{D}}-V$ characteristics are corrected for the built-in voltage, $V_{\mathrm{bi}}$, that arises from the work function difference between the contacts. 

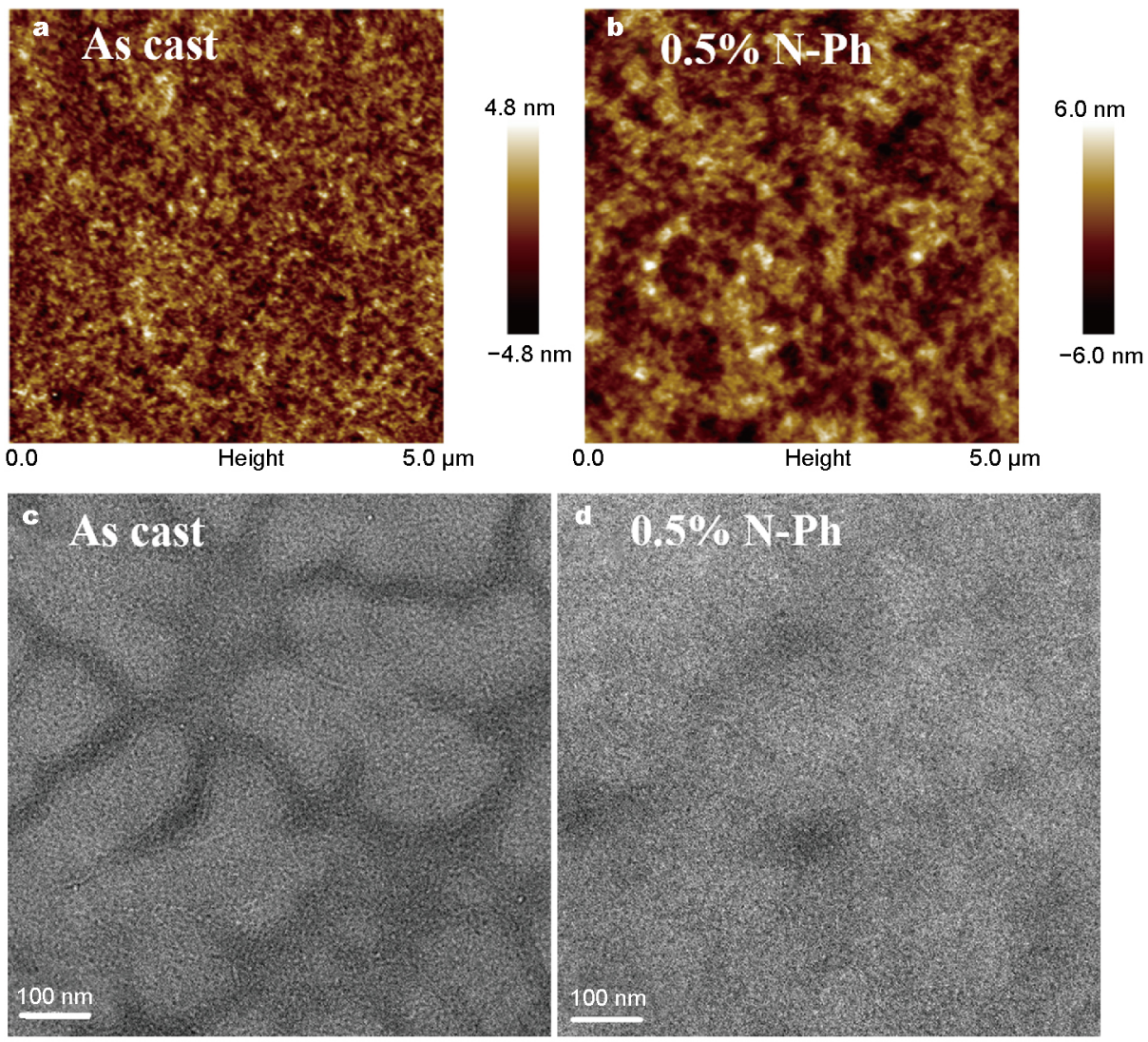

Figure $4 \operatorname{AFM}(a, b)$ and TEM images (c, d). ( $a$ and $c$ ) The as cast and (b and d) with 0.5\% N-Ph of PBDB-T:DCF-2HT-blend film.

appears after the addition of $0.5 \% \mathrm{~N}-\mathrm{Ph}(v / v)$, indicating high exciton dissociation and charge transport efficiency, and thus a significantly improved $J_{\mathrm{sc}}$ and FF.

\section{CONCLUSIONS}

In conclusion, an A-D-A-type small molecule, DCF-2HT, was designed and synthesized for use as an electron acceptor. The influence of alkyl chains on the optical and electrochemical properties and device performance were investigated. Compared to DICTF, the new molecule exhibits high-lying LOMO energy levels. Devices based on PBDB-T:DCF-2HT and PTB7-Th:DCF-2HT show PCEs of $5.71 \%$ and $4.83 \%$, respectively. A higher $V_{\text {oc }}$ was obtained compared to that of DICTF-based devices. The results demonstrate that side-chain engineering could be an effective strategy for designing new non-fullerene derivatives.

\section{Received 9 November 2016; accepted 30 November 2016;} published online 13 December 2016

1 Service RF. Outlook brightens for plastic solar cells. Science, 2011, 332: 293-293

2 Heeger AJ. Semiconducting polymers: the third generation. Chem
Soc Rev, 2010, 39: 2354-2371

3 Chen LM, Hong Z, Li G, et al. Recent progress in polymer solar cells: manipulation of polymer:fullerene morphology and the formation of efficient inverted polymer solar cells. Adv Mater, 2009, 21: $1434-1449$

4 Li Y. Molecular design of photovoltaic materials for polymer solar cells: toward suitable electronic energy levels and broad absorption. Acc Chem Res, 2012, 45: 723-733

5 Mishra A, Bäuerle P. Small molecule organic semiconductors on the move: promises for future solar energy technology. Angew Chem Int Ed, 2012, 51: 2020-2067

6 Zhou H, Yang L, You W. Rational design of high performance conjugated polymers for organic solar cells. Macromolecules, 2012, 45: 607-632

7 Liu Y, Zhao J, Li Z, et al. Aggregation and morphology control enables multiple cases of high-efficiency polymer solar cells. Nat Commun, 2014, 5: 5293

8 Roncali J, Leriche P, Blanchard P. Molecular materials for organic photovoltaics: small is beautiful. Adv Mater, 2014, 26: 3821-3838

9 Duan C, Furlan A, van Franeker JJ, et al. Wide-bandgap benzodithiophene-benzothiadiazole copolymers for highly efficient multijunction polymer solar cells. Adv Mater, 2015, 27: 4461-4468

$10 \mathrm{He}$ Z, Xiao B, Liu F, et al. Single-junction polymer solar cells with high efficiency and photovoltage. Nat Photon, 2015, 9: 174-179

11 Kan B, Li M, Zhang Q, et al. A series of simple oligomer-like small molecules based on oligothiophenes for solution-processed solar cells with high efficiency. J Am Chem Soc, 2015, 137: 3886-3893

12 Liu C, Yi C, Wang K, et al. Single-junction polymer solar cells 
with over $10 \%$ efficiency by a novel two-dimensional donor-acceptor conjugated copolymer. ACS Appl Mater Interfaces, 2015, 7: 4928-4935

13 Lu L, Zheng T, Wu Q, et al. Recent advances in bulk heterojunction polymer solar cells. Chem Rev, 2015, 115: 12666-12731

14 Zhang S, Ye L, Zhao W, et al. Realizing over $10 \%$ efficiency in polymer solar cell by device optimization. Sci China Chem, 2015, 58: 248-256

15 Chiu MY, Chen CC, Sheu JT, et al. An optical programming/electrical erasing memory device: organic thin film transistors incorporating core/shell CdSe@ZnSe quantum dots and poly(3-hexylthiophene). Org Electron, 2009, 10: 769-774

16 Dennler G, Scharber MC, Brabec CJ. Polymer-fullerene bulk-heterojunction solar cells. Adv Mater, 2009, 21: 1323-1338

17 He Z, Zhong C, Su S, et al. Enhanced power-conversion efficiency in polymer solar cells using an inverted device structure. Nat Photon, 2012, 6: 593-597

18 Zou S, Wang Y, Gao J, et al. Synthesis, characterization, and fieldeffect transistor performance of a two-dimensional starphene containing sulfur. J Mater Chem C, 2014, 2: 10011-10016

19 Lin Y, Zhan X. Non-fullerene acceptors for organic photovoltaics: an emerging horizon. Mater Horiz, 2014, 1: 470-488

$20 \mathrm{Ni}$ W, Li M, Kan B, et al. Fullerene-free small molecule organic solar cells with a high open circuit voltage of $1.15 \mathrm{~V}$. Chem Commun, 2016, 52: 465-468

21 Li S, Yan J, Li CZ, et al. A non-fullerene electron acceptor modified by thiophene-2-carbonitrile for solution-processed organic solar cells. J Mater Chem A, 2016, 4: 3777-3783

22 Li S, Liu W, Shi M, et al. A spirobifluorene and diketopyrrolopyrrole moieties based non-fullerene acceptor for efficient and thermally stable polymer solar cells with high open-circuit voltage. Energy Environ Sci, 2016, 9: 604-610

23 Zhong Y, Trinh MT, Chen R, et al. Molecular helices as electron acceptors in high-performance bulk heterojunction solar cells. Nat Commun, 2015, 6: 8242

24 Sun D, Meng D, Cai Y, et al. Non-fullerene-acceptor-based bulkheterojunction organic solar cells with efficiency over 7\%. J Am Chem Soc, 2015, 137: 11156-11162

25 Nielsen CB, Holliday S, Chen HY, et al. Non-fullerene electron acceptors for use in organic solar cells. Acc Chem Res, 2015, 48: 2803-2812

26 Lin Y, Wang J, Zhang ZG, et al. An electron acceptor challenging fullerenes for efficient polymer solar cells. Adv Mater, 2015, 27: $1170-1174$

27 Li H, Hwang YJ, Courtright BAE, et al. Fine-tuning the 3D structure of nonfullerene electron acceptors toward high-performance polymer solar cells. Adv Mater, 2015, 27: 3266-3272

28 Holliday S, Ashraf RS, Nielsen CB, et al. A rhodanine flanked nonfullerene acceptor for solution-processed organic photovoltaics. J
Am Chem Soc, 2015, 137: 898-904

29 Kim Y, Song CE, Moon SJ, et al. Rhodanine dye-based small molecule acceptors for organic photovoltaic cells. Chem Commun, 2014, 50: 8235-8238

30 Winzenberg KN, Kemppinen P, Scholes FH, et al. Indan-1,3-dione electron-acceptor small molecules for solution-processable solar cells: a structure-property correlation. Chem Commun, 2013, 49: 6307-6309

31 Zhao W, Qian D, Zhang S, et al. Fullerene-free polymer solar cells with over $11 \%$ efficiency and excellent thermal stability. Adv Mater, 2016, 28: 4734-4739

32 Lin Y, Zhao F, He Q, et al. High-performance electron acceptor with thienyl side chains for organic photovoltaics. J Am Chem Soc, 2016, 138: 4955-4961

33 Li M, Liu Y, Ni W, et al. A simple small molecule as an acceptor for fullerene-free organic solar cells with efficiency near $8 \%$. J Mater Chem A, 2016, 4: 10409-10413

34 Qin Y, Uddin MA, Chen Y, et al. Highly efficient fullerene-free polymer solar cells fabricated with polythiophene derivative. Adv Mater, 2016, 28: 9416-9422

35 Li S, Ye L, Zhao W, et al. Energy-level modulation of small-molecule electron acceptors to achieve over $12 \%$ efficiency in polymer solar cells. Adv Mater, 2016, 28: 9423-9429

36 Lin Y, Zhang ZG, Bai H, et al. High-performance fullerene-free polymer solar cells with $6.31 \%$ efficiency. Energy Environ Sci, 2015, 8: $610-616$

37 Bai $\mathrm{H}$, Cheng $\mathrm{P}$, Wang $\mathrm{Y}$, et al. A bipolar small molecule based on indacenodithiophene and diketopyrrolopyrrole for solution processed organic solar cells. J Mater Chem A, 2014, 2: 778-784

38 Zhang ZG, Qi B, Jin Z, et al. Perylene diimides: a thickness-insensitive cathode interlayer for high performance polymer solar cells. Energy Environ Sci, 2014, 7: 1966-1973

39 Qiu N, Zhang H, Wan X, et al. A new nonfullerene electron acceptor with a ladder type backbone for high-performance organic solar cells. Adv Mater, 2016

Acknowledgments This work was supported by the Ministry of Science and Technology (2014CB643502 and 2016YFA0200200) and the National Natural Science Foundation of China (21404060 and 91433101)

Author contributions Liu $\mathrm{Y}$ and Zhang $\mathrm{H}$ proposed and designed the project, and Zhang $\mathrm{H}$ directed the study. Sun $\mathrm{Y}$ and Wan $\mathrm{X}$ fabricated and characterized the devices. Liu Y and Zhang $\mathrm{H}$ wrote the paper, with support from Chen Y. All authors contributed to the general discussion.

Conflict of interest The authors declare that they have no conflict of interest.

Supplementary information Supplementary data are available in the online version of the paper. 


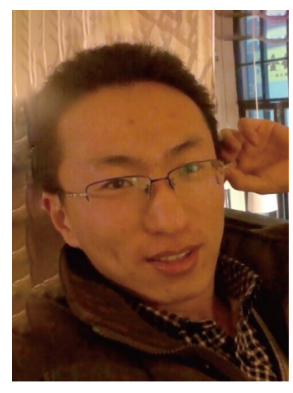

Yongtao Liu is a PhD candidate under the supervision of Prof. Yongsheng Chen at Nankai University. He received his BSc degree in chemistry from Nankai University in 2014. His research focuses on the design and synthesis of small molecules for organic solar cells.

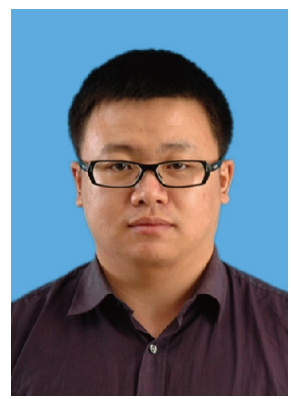

Hongtao Zhang received his $\mathrm{PhD}$ degree in 2012 at the Institute of Chemistry, Chinese Academy of Sciences. He joined Prof. Yongsheng Chen's group at Nankai University in 2014. His current research interests include OPV and OFET devices.

\section{己基取代噻吩为桥的“受体-给体-受体”型小分子作为非富勒烯太阳电池受体的研究}

刘勇涛 ${ }^{1}$ 张洪涛 ${ }^{1,2^{*}}$, 孙延娜 ${ }^{1,2}$, 万相见 ${ }^{1,2}$, 陈永胜 1,2

摘要 本文合成了一个以芴为中心核, 已基取代噻吩为桥, 双氰基狮满二酮为端基的“受体-给体-受体”型小分子(DCF-2HT), 并对基于给体 材料为PBDB-T/PTB7-Th, 受体为DCF-2HT的太阳能电池器件光伏性能进行了研究. 经过一系列形貌优化, 以0.5\%甲基荟为添加剂, PBDB-T 和PTB7-Th为给体材料的器件效率分别优化至 $5.71 \%$ 和 $4.83 \%$. 